\title{
SPECTROPHOTOMETRIC AND DERIVATIVE SPECTROPHOTOMETRIC DETERMINATION OF ALUMINIUM WITH HYDROXYNAPHTHOL BLUE
}

\author{
Sérgio l C Ferreira, Neide O. leite, Alailson F. Dantas, Jallson B. de Andrade and \\ A. C. Spinola Costa \\ Instıtuto de Quimıca, Unıversıdade Federal da Bahı, Campus Unıversıtáno da Federação, Salvador, \\ Ba-Brasıl, 40170280 , Brazıl
}

(Recewed 29 September 1993 Revised 2 March 1994 Accepted 7 March 1994)

\begin{abstract}
Summary-The reaction of aluminium(III) with Hydroxynaphtol Blue (HNB) in aqueous media at apparent pH 55 results in a red complex that is stable for at least $4 \mathrm{hr}$ Beer's Law is obeyed up to 16 $\mu \mathrm{g} / \mathrm{ml}$ of aluminium(III) with an apparent molar absorptıvity of $166 \times 10^{4} 1 \mathrm{~mol}^{-1} \mathrm{~cm}^{-1}$ at $569 \mathrm{~nm}$ This paper proposes procedures for aluminium(III) determınation by ordinary and first-derıvatıve spectrophotometry. The results demonstrated that the linear dynamic range is $003-160 \mu \mathrm{g} / \mathrm{ml}$ for ordinary spectrophotometry and $118-3200 \mathrm{ng} / \mathrm{ml}$ for first derivative spectrophotometry The HNB is not selectivity for aluminium, but the addition of EDTA allows the aluminum determination in the presence of accepted amounts of $\mathrm{Ca}(\mathrm{II}), \mathrm{Mg}$ (II), $\mathrm{Mn}$ (II), $\mathrm{Ba}$ (II), $\mathrm{Sr}(\mathrm{II}), \mathrm{Cd}(\mathrm{II}), \mathrm{Pb}$ (II), $\mathrm{La}(\mathrm{III}), \mathrm{In}(\mathrm{III}), \mathrm{B}$ (III) and $\mathrm{Zn}$ (II) The interference of $\mathrm{Cu}(\mathrm{II})$ and $\mathrm{Hg}$ (II) can be masked by thiosulphate Ions such as $\mathrm{UO}_{2}$ (II), $\mathrm{Mo}$ (VI), $\mathrm{Co}(\mathrm{II}), \mathrm{TI}(\mathrm{IV})$ and $\mathrm{PO}_{4}$ (III) do interfere senously This method was applied for aluminium determination in copper-base alloy, zinc-base alloy, magnestum-base alloy, iron ore, manganese ore, cement, dolomite, feldspar and limestone The results indicated high accuracy and precision
\end{abstract}

Numerous spectrophotometric methods for aluminium determination have been published, normally these methods are not simple and usually they have low confiability. The most frequently reagents used are 8-hydroxyquinoline, aluminon, eriochrome cyanine $\mathrm{R}$, chrome azurol $S$ and stilbazo.'

8-Hydroxyquinoline ${ }^{2}$ is not very sensitive, but with the use of appropriate masking agents it is highly selective. This method is widely used, but requires extensive and laborious extraction steps. Eriochrome cyanine $\mathbf{R}^{2}$ is one of the most sensitive spectrophotometric reagents for aluminium determination, but the complex formation is greatly influenced by $\mathrm{pH}$; the stoichiometry is even observed to change with variation in $\mathrm{pH}$. Chrome azurol $\mathrm{S}^{2}$ has been widely applied, but the aluminium complex solution does not obey Beer's Law and the absorbance signal is very influenced by the reagent concentration. Aluminon ${ }^{1}$ is also an important reagent, it reacts with aluminium(III) cation formıng a lake and, protective colloids such as gelatin, acacia gum, arabic gum or surfactants must be used to stabilize the formed lake. The rate of lake formation is very slow and in many cases, require heating of the reagents at $100^{\circ} \mathrm{C}$. Stilbazo' reacts with aluminium(III) ions forming a lake. The color develops in $10 \mathrm{~min}$ and is stable for $\mathbf{4 5} \mathrm{min}$. This reagent cannot be used in the presence of high concentrations of electrolytes because of salting out. Many procedures with it have been proposed

In aqueous weakly acid media, the instantaneous reaction of the aluminium(III) cation with the Hydroxynaphtol Blue (HNB) reagent provides a new spectrophotometric method for aluminium determınation. The use of EDTA as masking agent increase the selectivity of the proposed procedure. A derivative spectrophotometric method is also proposed and have higher sensitivity than the ordinary method.

HNB was proposed as spectrophotometric reagent by Brittain. ${ }^{4}$ In his study, HNB was used for determination of alkaline earth and lanthanıde elements. In another paper, he indicated the use of HNB for spectrophotometric and fluorimetric determination of uranium. ${ }^{4} \mathrm{Re}$ cently Farias and co-workers' proposed the use of HNB for nickel determination by cathodic adsorptive stripping voltammetry 


\section{EXPERIMENTAL}

\section{Reagents}

All reagents were of analytical reagent grade unless otherwise stated.

Aluminium(III) solution $(1000 \mu \mathrm{g} / \mathrm{ml})$. Prepared by dissolving pure aluminium $(99.99 \%)$ in diluted hydrochloric acid and dissolution up to 1 I with demineralized water

$H N B$ solution $(0.25 \%)$. Prepared by dissolving $025 \mathrm{~g}$ (Merck) in $100 \mathrm{ml}$ of demineralızed water. This solution should be prepared weekly.

Buffer solution (pH 5.5). Prepared by mixing $74.6 \mathrm{~g}$ of anhydrous sodium acetate and $5.3 \mathrm{ml}$ of glacial acetic acid in 11 . of demineralızed water.

EDTA solution $(0.20 \%)$. Prepared by dissolving $020 \mathrm{~g}$ of EDTA disodium salt (Merck) in $100 \mathrm{ml}$ of demineralized water.

Sodlum thiosulfate solution (10\%). Prepared by dissolving sodium thiosulfate pentahydrate in demineralızed water.

\section{Apparatus}

Absorption spectra, first-derivative spectra and absorbances were recorded and measured with a Varian DMS-80 spectrophotometer and a Intralab recorder using $10-\mathrm{cm}$ cells. A 300 Analyser $\mathrm{pH}$ meter was used to measure the $\mathrm{pH}$ values

\section{General procedure}

Spectrophotometric determination of aluminium (procedure $A$ ). A portion of solution containing $1000 \mu \mathrm{g}$ of aluminium(III) was transferred to a $25 \mathrm{ml}$ standard flask, $50 \mathrm{ml}$
HNB $0.25 \%$ and $50 \mathrm{ml}$ acetate buffer (pH 5.5) added, mixed and after $10 \mathrm{~min} 2.0 \mathrm{ml}$ EDTA solution $020 \%$ added and diluted to the mark with water The absorbance at $569 \mathrm{~nm}$ was measured in a $1-\mathrm{cm}$ cell, using an appropriate blank. A calibration curve covering the range from 4.0 to $40.0 \mu \mathrm{g}$ of aluminium(III) per $25 \mathrm{ml}$ was prepared.

First-derwatuve spectrophotometry (procedure $B)$. A portion of solution contaıning $4.00 \mu \mathrm{g}$ of aluminium(III) was transferred to a $25 \mathrm{ml}$ standard flask Then $50 \mathrm{ml}$ of HNB $025 \%, 5.0 \mathrm{ml}$ acetate buffer ( $\mathrm{pH} 55$ ) were added and mixed. After $10 \mathrm{~min} 500 \mu 1$ of EDTA solution $(020 \%)$ was added, diluted to the mark with water, mixed and the first-derivative spectrum from 800 to $500 \mathrm{~nm}$ recorded against an appropriate blank, at a scan speed of $100 \mathrm{~nm} / \mathrm{m}$ n and slit of $4 \mathrm{~nm}$.

The first-derivatıve sıgnal amplitude $(H)$ was measured with the recorder voltage 10 or $5 \mathrm{mV}$.

A calibration curve covering the range from 0.5 to $8.0 \mu \mathrm{g}$ of alumınıum(III) per $25 \mathrm{ml}$ was prepared

\section{RESULTS AND DISCUSSION}

Characteristics of the reagent and the complex

The 1-(2-naphthalazo-3,6-disulfonic acid)-2naphtol-4-sulfonic acid, Hydroxynaphtol Blue (HNB), is an $o, o^{\prime}$-dihidroxyarylazo compound, whose trisodium salt has high solubility in water. The aluminium(III) cation reacts with it forming a red complex with absorption maximum at $569 \mathrm{~nm}$. The complex is formed immediately and is stable for at least $4 \mathrm{hr}$ The

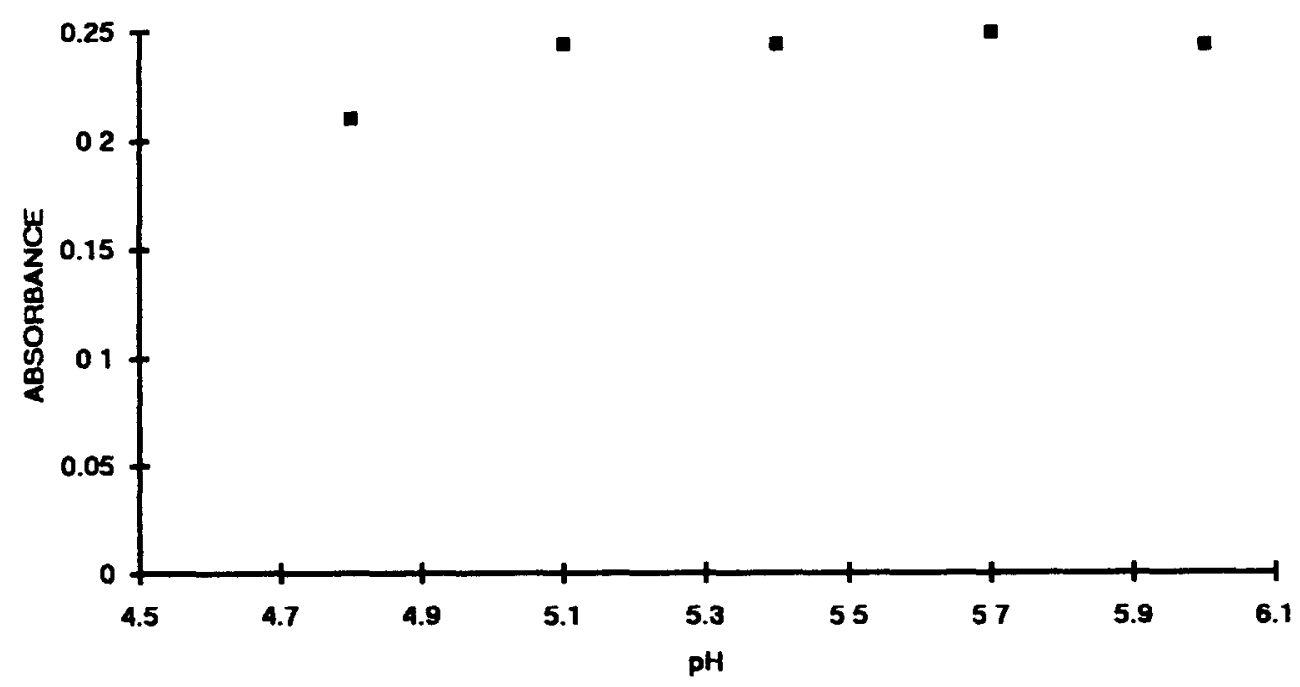

Fig 1 Effect of the $\mathrm{pH}$ on the Al(III)-HNB system $\left[\mathrm{Al}^{3+}\right]=1000 \mu \mathrm{g} / 25 \mathrm{ml},\left[\right.$ EDTA] $=537 \times 10^{-4} \mathrm{M}$, $[\mathrm{HNB}]=005 \%$ 
Table 1 Effect of the order of addition

\begin{tabular}{lc}
\hline Order of addition & $\begin{array}{c}\text { Absorbance } \\
\text { at } 569 \mathrm{~nm}\end{array}$ \\
\hline Al(III) + HNB + buffer & 0254 \\
Al(III) + buffer + HNB & 0252 \\
Al(III) + HNB + buffer + EDTA & 0242 \\
Al(III) + buffer + HNB + EDTA & 0247 \\
Al(III) + HNB + EDTA + buffer & 0048 \\
Al(III) + buffer + EDTA + HNB & 0002 \\
Al(III) + EDTA + HNB + buffer & 0002 \\
Al(III) + EDTA + buffer + HNB & 0001 \\
\hline
\end{tabular}

HNB reagent has a absorption maximum at 529 $\mathrm{nm}$ (at pH 5 ).

\section{Effect of $p H$}

The effect of the $\mathrm{pH}$ on the aluminium (III)-HNB system was studied and the results demonstrated that the absorbance signal is maximum and constant in a $\mathrm{pH}$ range of 5.1-6.0 (Fig. 1). The general procedure was developed with an acetate buffer at $\mathrm{pH} 5.5$, because at this $\mathrm{pH}$, the buffer-index of the acetate buffer is higher than at $\mathrm{pH} 6$.

Effect of the amount of acetate buffer solution

The effect of the buffer concentration on the alumınium(III)-HNB complex was studied and the results demonstrated that it does not affect the absorbance signal of the system when the buffer is in the concentration range of $0.1-0.4 M$ in acetate.

Effect of the order of addition of reagents on the complex formation

The addition order of the reagents was studied and the results demonstrated that the com- plex formation was affected by it The EDTA must be added after the complex formation of the aluminium(III)-HNB, that is only formed after the reaction between aluminium(III) ions with $\mathrm{HNB}$ and $\mathrm{pH}$ adjustment with addition of the buffer solution (Table 1). The EDTA must be added after $10 \mathrm{~min}$ of the complex formation of the chromogenic complex, simply to guarantee the stabilization.

Effect of the EDTA amount on the aluminium (III) - HNB complex

HNB is not a selective reagent for aluminium determination However, the use of EDTA as masking agent solves this inconvenience. The effect of the amount of EDTA on the aluminum (III)-HNB system was studied and the results (Fig 2) showed that it can be used as a masking agent when present with a concentration for up to of $1.30 \times 10^{-3} \mathrm{M}$. The presence of EDTA does not affect the stability of the system for at least $4 \mathrm{hr}$, as can be seen in Fig. 3 .

\section{Amount of $H N B$ for complex formation}

A maximal and constant absorbance signal was obtained for $10.00 \mu \mathrm{g}$ of aluminium(III) with $1.0 \mathrm{ml}$ of $0.25 \% \mathrm{HNB}$ solution per $25 \mathrm{ml}$. Thus, $5.0 \mathrm{ml}$ of HNB solution was selected as optimal for the general procedure.

Conditions for the measurement of first-derivatwe value

The absorption spectra and first-derivative spectrum of the aluminium(III)-HNB complex is shown in Fig. 4. Effects of the scan speed and

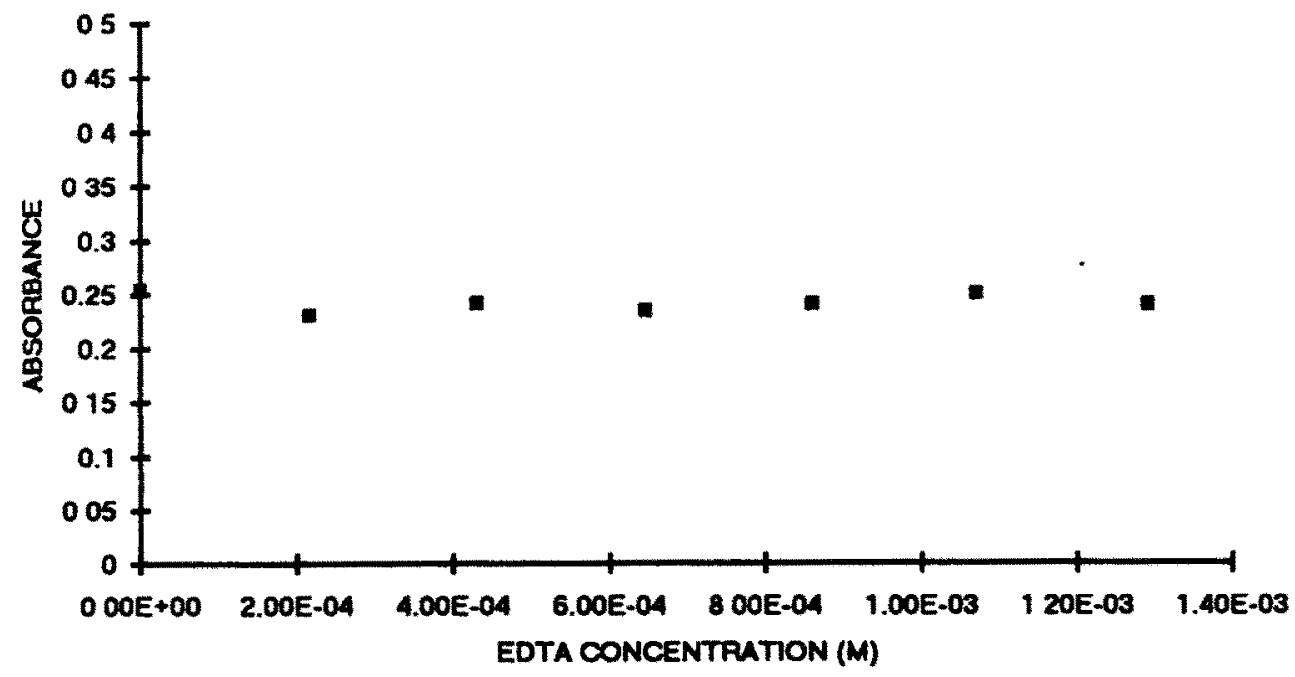

Fig 2 Effect of EDTA amount on the Al(III)-HNB system $\left[A P^{3+}\right]=1000 \mu \mathrm{g} / 25 \mathrm{ml}$, [HNB] $=005 \%$, $\mathrm{pH} 550$ 


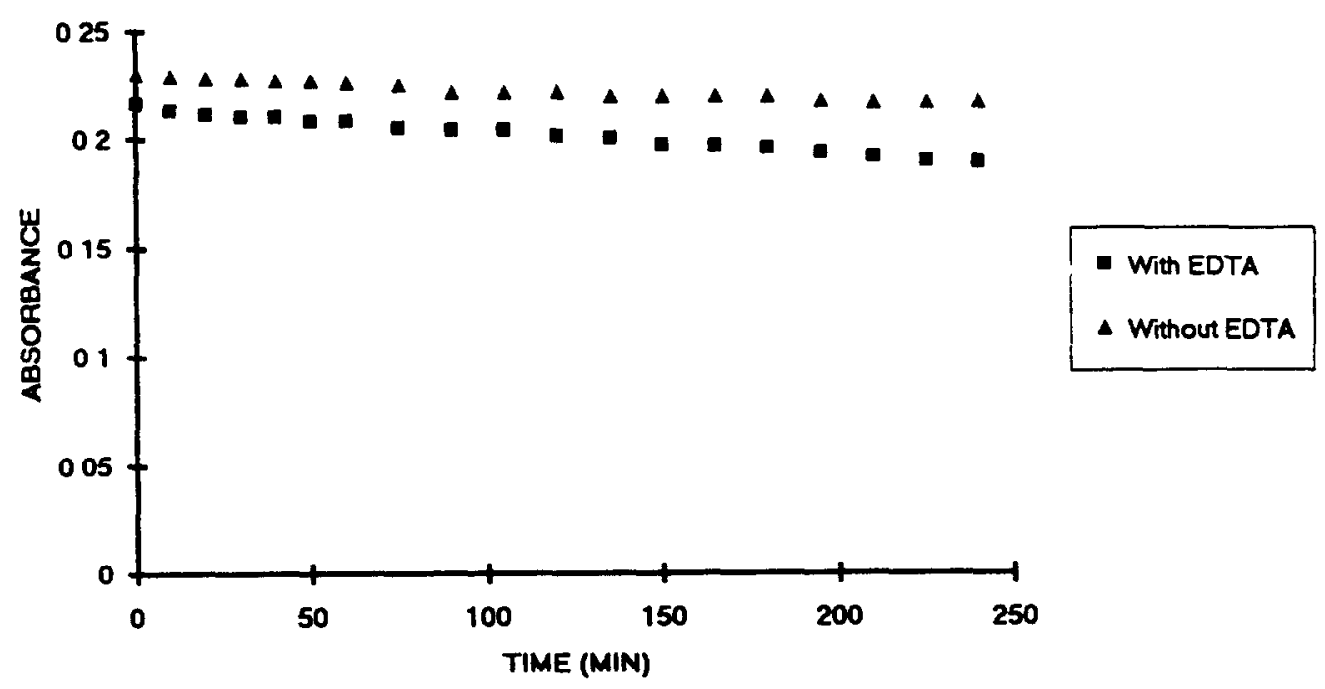

Fig 3 Effect of EDTA on the stability of the Al(III)-HNB system $\left[\mathrm{Al}^{3+}\right]=1000 \mu \mathrm{g}, 25 \mathrm{ml}$, $\left[\right.$ EDTA] $=130 \times 10^{-3} M, \mathrm{pH} 550$

of the slit width $(\Delta l)$ were examined on the measurement of the first-derivative signal. The results showed that scan speed did not affect the value In this way, the scan speed of $100 \mathrm{~nm} / \mathrm{min}$ was chosen It was also found that there was no significant difference in sensitivity among varıous $\Delta l$ 's, but the increase of slit width decreased the noise, hence a slit of $4 \mathrm{~nm}$ was selected in the measurements. The decrease of recorder voltage obviously does increase the first-derivative signal but also increase the notse.

The method used for the quantitative evaluation of derivatıve spectra signal is classificated as the 'Peak-zero method'.

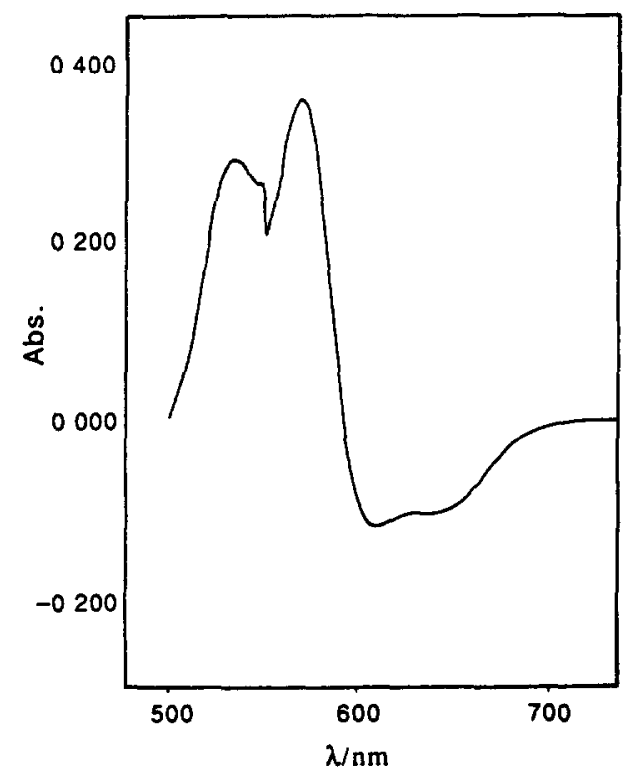

\section{Effect of interfering ions}

Solutions containing $10.00 \mu \mathrm{g}$ of aluminium (III) and various proportions of several cations and anions were prepared and procedure $A$ was followed. The interference limit of an ion was defined as the proportion in which a change of $\pm 2 \%$ in absorbances of the chelates were observed. The results are listed in Table 2 .

The interference of mercury(II) and copper (II) can be masked with thiosulfate or thiourea. The addition of $200 \mathrm{mg}$ of sodium thiosulphate is enough to mask $1000 \mu \mathrm{g}$ of copper(II) cation. Fluoride does interfere seriously but its interfer-

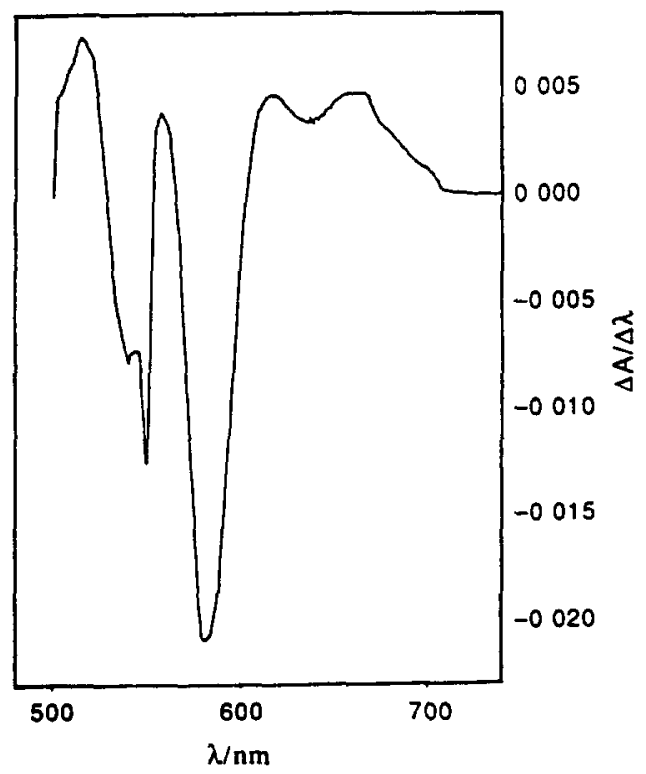

Fig 4 The absorption spectra and derivative spectrum of the $\mathrm{Al}(\mathrm{III})-\mathrm{HNB}$ complex $\left[\mathrm{Al}^{3+}\right]=1000 \mu \mathrm{g} / 25$ $\mathrm{ml},[\mathrm{EDTA}]=537 \times 10^{-4} \mathrm{M},[\mathrm{HNB}]=005 \%, \mathrm{pH} 550$ 
Table 2 Aluminium determination in the presence of various ions

\begin{tabular}{|c|c|c|c|c|c|}
\hline Ion & $100 \times 1$ & $10 \times 1$ & $1 \times 1$ & $\begin{array}{l}\text { Allowed } \\
\text { proportion }\end{array}$ & Reagent used \\
\hline $\mathrm{Pb}(\mathrm{II})$ & $\mathbf{N}$ & $\mathbf{N}$ & $\mathbf{N}$ & - & $\mathrm{Pb}\left(\mathrm{NO}_{3}\right)_{2}$ \\
\hline $\mathrm{Mn}(\mathrm{II})$ & $N$ & $\mathbf{N}$ & $\mathbf{N}$ & - & $\mathrm{MnSO}_{4} 6 \mathrm{H}_{2} \mathrm{O}$ \\
\hline $\operatorname{Sr}(I I)$ & $\mathbf{N}$ & $\mathbf{N}$ & $\mathbf{N}$ & - & $\mathrm{Sr}\left(\mathrm{NO}_{3}\right)_{2}$ \\
\hline $\mathrm{Ba}(\mathrm{II})$ & $\mathbf{N}$ & $\mathbf{N}$ & $\mathbf{N}$ & - & $\mathrm{BaCl}_{2} 2 \mathrm{H}_{2} \mathrm{O}$ \\
\hline $\mathrm{Ca}(\mathrm{II})$ & $\mathbf{N}$ & $\mathrm{N}$ & $\mathbf{N}$ & - & $\mathrm{CaCO}_{3} / \mathrm{HCl}$ \\
\hline $\mathrm{Mg}(\mathrm{II})$ & $\mathrm{N}$ & $\mathbf{N}$ & $\mathbf{N}$ & - & $\mathrm{MgCl}_{2} 6 \mathrm{H}_{2} \mathrm{O}$ \\
\hline $\mathrm{La}(I I I)$ & 1 & $\mathbf{N}$ & $\mathrm{N}$ & $80 x$ & $\mathrm{LaCl}_{3} 7 \mathrm{H}_{2} \mathrm{O}$ \\
\hline In(III) & I & $\mathbf{N}$ & $\mathbf{N}$ & $50 \times$ & $\mathrm{In}_{2} \mathrm{O}_{3} / \mathrm{HCl}$ \\
\hline $\mathrm{Zn}(\mathrm{II})$ & I & $\mathbf{N}$ & $\mathbf{N}$ & $40 x$ & $\mathrm{ZnSO}_{4} 7 \mathrm{H}_{2} \mathrm{O}$ \\
\hline $\mathrm{Cu}(\mathrm{II})^{*}$ & I & $\mathbf{N}$ & $\mathbf{N}$ & $50 \times$ & $\mathrm{CuSO}_{4} 5 \mathrm{H}_{2} \mathrm{O}$ \\
\hline Fe(III) & I & I & $\mathbf{N}$ & $10 x$ & $\mathrm{Fe}_{2}\left(\mathrm{SO}_{4}\right)_{3} / \mathrm{HCl}$ \\
\hline $\mathrm{N}$ (II) & 1 & I & $\mathbf{N}$ & $5 x$ & $\mathrm{~N}_{\mathrm{iSO}}+7 \mathrm{H}_{2} \mathrm{O}$ \\
\hline $\mathrm{T} 1(\mathrm{IV})$ & 1 & I & $\mathbf{N}$ & $2 \times$ & $\mathrm{T}_{1} \mathrm{O}_{2} / \mathrm{H}_{2} \mathrm{SO}_{4}$ \\
\hline $\mathrm{Hg}(\mathrm{II})^{*}$ & I & I & $\mathbf{N}$ & - & $\mathrm{HgO} / \mathrm{HNO}_{3}$ \\
\hline $\mathrm{Co}(\mathrm{II})$ & I & I & $\mathbf{N}$ & - & $\mathrm{CoSO}_{4} 7 \mathrm{H}, \mathrm{O}$ \\
\hline $\mathrm{Fe}(\mathrm{II})^{*+}$ & I & I & I & - & $\mathrm{Fe}(\mathrm{III}) / \mathrm{NH}_{2} \mathrm{OH} \mathrm{HCl}$ \\
\hline $\mathrm{F}(\mathrm{I})_{+}^{+}$ & I & I & $\mathbf{N}$ & - & $\mathrm{NaF}$ \\
\hline $\mathrm{PO}_{4}(\mathrm{III})$ & $\mathbf{I}$ & I & $\mathbf{N}$ & - & $\mathrm{NaPO}_{4}$ \\
\hline
\end{tabular}

* High concentrations can be masked with thıosulphate

tEasily masked by oxidation with nitric acid

†Interference elımınated by heatıng with sulphuric acıd

Table 3 Analytical characteristics of the procedures

\begin{tabular}{lcc}
\hline & $\begin{array}{c}\text { Ordinary } \\
\text { spectrophotometric }\end{array}$ & $\begin{array}{c}\text { First-derivative } \\
\text { spectrophotometric }\end{array}$ \\
\hline Calıbration sensitivity & $0617 \mathrm{ml} / \mu \mathrm{g}$ & $473 \mathrm{ml} / \mu \mathrm{g}$ \\
Analytical sensitivity & $23822 \mathrm{ml} / \mu \mathrm{g}$ & $63575 \mathrm{~cm} / \mathrm{ml} / \mu \mathrm{g}$ \\
Limit of detection & $1021 \mathrm{ng} / \mathrm{ml}$ & $356 \mathrm{ng} / \mathrm{ml}$ \\
Limit of quantification & $3404 \mathrm{ng} / \mathrm{ml}$ & $118 \mathrm{ng} / \mathrm{ml}$ \\
Linear dynamic range & $003-160 \mu \mathrm{g} / \mathrm{ml}$ & $118-320 \mathrm{ng} / \mathrm{ml}$ \\
Coefficient of variation & $046 \%$ & $079 \%$ \\
\hline
\end{tabular}

ence can be easily eliminated by the heatıng solution in the presence of sulphuric acid or perchloric acid. The effect of ionic strength on the alumınium(III)-HNB system is negligıble for $0.1 \mathrm{M}$ concentrations of sodium chloride and potassium nitrate.

\section{Analytical characteristics of the method}

The calibration curves were determıned as described in the procedure A (for ordinary spectrophotometric method) and procedure B for first-derivatıve method The calibration sensitivity, ${ }^{7}$ limit of detection $C_{\mathrm{L}}{ }^{8}$ as well as other analytical characteristıcs of the method are summarized in the Table 3. Obviously, the derivative method is more sensitive than the ordinary spectrophotometric method.

Table 4 Aluminium determination in standards

\begin{tabular}{lccc}
\hline Standards & $\begin{array}{c}\text { Alumınıum } \\
\text { certıfied }\end{array}$ & $\begin{array}{c}\text { Aluminium } \\
\text { found }\end{array}$ & $(N)$ \\
\hline $\begin{array}{l}\text { Zinc-base alloy } \\
\text { NIST 94c }\end{array}$ & $413 \%$ & $413 \pm 006 \%$ & $(4)$ \\
$\begin{array}{l}\text { Copper-base alloy } \\
\text { NIST 164 }\end{array}$ & $621 \%$ & $624 \pm 004 \%$ & $(5)$ \\
Iron ore IPT 23 & $059 \%$ & $059 \pm 001 \%$ & $(5)$ \\
\hline
\end{tabular}

\section{Application}

The proposed method (procedure A) was applied for aluminıum determination in copperbase alloy, zınc-base alloy. magnesium-base alloy, Iron ore, manganese ore, cement, dolomite, feldspar and limestone Results are described in Tables 4 and 5.

The results of the Table 4 demonstrate that there is no significant difference between the certıfied value and the found value with $\mathrm{HNB}$ at the $95 \%$ confidence level. The paired $t$ test $^{9}$ was applied to the results of Table 5 and it revealed that there is no significant difference between the ICP method and the HNB method in aluminium determination to these matrices at the $95 \%$ confidence level.

Table 5 Alumınıum determınation in samples

\begin{tabular}{lcr}
\hline Samples & ICP method & \multicolumn{1}{c}{ HNB method } \\
\hline Cu-base alloy & $138 \%$ & $149 \pm 001 \%(3)$ \\
Mg-base alloy & $278 \%$ & $264 \pm 004 \%(5)$ \\
Feldspar & $1049 \%$ & $1036 \pm 025 \%(3)$ \\
Limestone & $080 \%$ & $083 \pm 004 \%(3)$ \\
Manganese ore & $458 \%$ & $464 \pm 008 \%(3)$ \\
Dolomite & $034 \%$ & $033 \pm 002 \%(3)$ \\
Cement & $011 \%$ & $010 \pm 001 \%(3)$ \\
\hline
\end{tabular}


Sample preparation of geological matrices ${ }^{10}$ were made using hydrochloric acid, sulphuric acid and hydrofluoric acid, copper-base alloy and zinc-base alloy with nitric acid and magnesium-base alloy with hydrochlonc acid. In copper-base alloy, the copper was masked with thiosulphate ${ }^{\prime \prime}$ and in iron ore, the iron(III) cation was extracted ${ }^{12}$ as chloride complex using the ethyl acetate as extractor solvent.

Procedure B was applied for alumınium determination in synthetic aqueous solutions contaınıng iron(III), magnesıum(II) and calcium (II). The results demonstrated that this method can be used for aluminium determination in fresh water

\section{CONCLUSIONS}

The proposed method can be applied for spectrophotometric determination of aluminium in matrices that do not contain significant amounts of interferents such as titanium(IV), iron(II), molybdenum(VI), cobalt(II), uranyl(II) and phosphate. Titanium(IV) cation is one of the main interferent in aluminium determination with HNB. However, the alumınium amounts in several geological matrices is much higher than the titanium amounts.

EDTA can be used as masking agent because its reaction with aluminium(III) cation is very slow, when carried out at ordinary temperature and in weakly acid medium, on the other hand the aluminium(III) cation reaction with HNB is instantaneous

The application of the proposed method Indicated that it has very good accuracy and precision. As a result, the proposed method is useful for routıne analysis owing to its simplicity comparable with another methods described in the Introduction section.

Acknowledgements - The authors acknowledge the financial support of the CNP, FINEP and CAPES

\section{REFERENCES}

1 F D Snell, Photometric and Fluorometric Methods of Analysts, Part 1, p 585 Wiley, New York. 1978

$2 \mathrm{Z}$ Marczenko, Spectrophotometric Determination of Elements, p 110 Horwood, Chichester, 1976

3 H G Brittain, Anal Chem, 1977, 49, 969

4 H G Brittain, Anal Lett, 1977, 10, 263

5 P A M Fanas, A K Ohara, I Takase, S L C Ferretra and J S Gold, Talanta, 1993, 40, 1167

6 K Laqua, W H Melhuish and M Zander. Pure Appl Chem, 1988, 60, 1449

7 D A Skoog and J J Leary, Principles of Instrumental Analysis, p 7 Saunders College Publıshing. Florida. 1992

8 J Medinilla, F Ales and F Garcia Sanchez, Talanta, 1986, 33, 329

9 G Chirstian, Analyucal Chemistry, p 75 Wiley, New York, 1980

10 S L C Ferreira, A C S Costa, Ma G M Andrade and $N$ O Lette, Anal Lett, 1993, 26, 1001

11 S L C Ferreırd, Talanta, 1988, 35, 485

12 E B Sandell and H Onishi, Photometric Determination of Traces of Metals. Vol 3, Part 1, p 841 Wiley, New York, 1978 